\title{
Microscopic Studies Of The Effect Of Some Food Additives On The Kidney Of Albino Rat
}

\author{
Abd El-Tawab M. Ismail - Ashraf M.Moustafa \\ and Gamal Abd El-Rhman B.
}

\author{
Histology Department, Faculty of Medicine Al-Azhar University
}

\begin{abstract}
Recently the use of synthetic food coloring additives was increased and the levels of human exposure to such agents are very broad, thus feeding over long periods may continually possess potential hazards to the human health. Also most of the food colors tested in the conventional toxicity experiments showed toxic effects at very high level of intake i.e. 1-5\% in the diet.

The aim of this study was to evaluate the histological and histochemical effects of some of these substances (Sodium nitrate and sunset yellow) on the liver of adult albino rats. The study included three main parts:

A. Histological studies on the liver under the effect of (Sodium nitrate and sunset yellow) substances. Using paraffin sections, which were stained with $\mathrm{Hx} \&$ Eosin, Masson Trichrome

B. Evaluation of histochemical activity of both alkaline phosphates enzyme and succinic dehydrogenase enzymes on the renal tissue.

C. Statistical evaluation using image analyzer to detect glomerular area, area percentage of collagen fibers distribution and optical density of both alkaline phosphatase enzyme activity in glomerulus and succinic dehydrogenase enzyme activity in renal tubules. Seventy adult male albino rats were used. Nitrate and sunset yellow were given orally through a gastric tube in dose of $1 \mathrm{mg} / \mathrm{kg} / \mathrm{b}$.w. daily. The animals were classified into seven groups.
\end{abstract}

1. Group I (Control group)

2. Group II: The animals were given sodium nitrate in a dose of $1 \mathrm{mg} / \mathrm{kg} / \mathrm{bwt}$ for one month.

3. Group III: The animals were given sun set yellow in a dose of $1 \mathrm{mg} / \mathrm{kg} / \mathrm{bwt} / \mathrm{day}$ for one month.

4. Group IV: The animals were given sodium nitrate and sunset yellow for one month in a dose of $1 \mathrm{mg} / \mathrm{kg} / \mathrm{bwt} /$ for each drug in a separate manner.

5. Group V: The animals were given sodium nitrate similar to the previous dose as group II for one month and left 2 weeks without oral intubations.

6. Group VI: The animals were given sun set yellow No 6 in a dose and route of administrations as group III for one month and kept without intubations for 2 weeks.

7. Group VII: The animals were given both sodium nitrate \& sunset yellow by the same dose and route of administration as in group IV for one month and kept without intubations for 2 weeks.

\section{Introduction}

Food additives are common in our life and plays an important role in human being's life. Nitrate and nitrite are ubiquitous in nature and their presence are essential for the fertility of the soil, and used as international food additive added to the original food or mixture of foods for specific purposes (Kilgore and Li., 1980).

The continuous use of nitrogenous fertilization in agriculture is the major source 
of nitrate and nitrite which have been shown to be present in a wide variety in relatively high concentration (Walker, 1975). Nitrate itself is not toxic to mammals but it can be reduced to nitrite, most importantly by bacterial action during the storage of nitrate containing food. (Swann, 1975).

Synthetic food coloring additives are products from modern organic chemistry, which have been added to the list of additives used by the food industries. However, the available literature regarding their toxicity or metabolism revealed that little work has been published in the last decade (El-saadany, 1991).

Colors as an additives pigment or other substances synthesized, extracted, isolated or otherwise derived from vegetables or other sources (Furia, 1972; Shaker et al., 1989).

Coloring additives are vital constituents of food. They are probably the first characteristics perceived by the senses and are indispensable to the modern day consumer as a means for the rapid identification and affiants acceptance of food (Furia, 1972; Taylor, 1980; Marmian, 1984; Babu \& Shenalikar, 1995).

In recent years colors have attracted more attention than any other food additives, because they are the most obvious cosmetics and partially because people have made connection between some artificial dyes and adverse reactions to food (Marmian, 1984).However such levels of intake is not normally encountered. Therefore, more attention has been forced on the biological activity and effect of such colors which include chemical and physical specifications, short term and long term toxicity, carcinogenicity and metabolic studies (Salah, 1994; Babu \&

Shenolikar, 1995).

\section{Material And Methods}

Seventy male albino rats (Rattus Novigisus) were used in of average body weight about $120 \mathrm{gms}$ and there average age about 2 months.

The animals were divided into 7 groups 10 rats / each. Each group of animals were placed in stain steel cage \& maintained on standard pellet diet $\&$ water.
The substances used in this study were sodium nitrate and sunset yellow; both of them are available in powder form. Both of substance is given orally by gastric tube in a dose (1mglbwlday). The dose was calculated according ( Paget and Barnes 1964)

The animals were divided into 7 main roups (10 rats /each).

1-Group I (Control group)

2-Group II: The animals were given odium nitrate in a dose of $1 \mathrm{mg} / \mathrm{kg} / \mathrm{b}$ wt for one month.

3-Group III: The animals were given sun set yellow in a dose of $1 \mathrm{mg} / \mathrm{kg} / \mathrm{bwt} /$ day for one month.

4-Group IV: The animals were given sodium nitrate and sunset yellow for one month in a dose of $1 \mathrm{mg} / \mathrm{kg} / \mathrm{bwt} /$ for each drug in a separate manner.

5-Group V: The animals were given sodium nitrate similar to the previous dose as group II for one month and left 2 weeks without oral intubations.

6-Group VI: The animals were given sun set yellow No 6 in a dose and route of administrations as group III for one month and kept without intubations for 2 weeks.

7-Group VII: The animals were given both sodium nitrate \& sunset yellow by the same dose and route of administration as in group IV for one month and kept without intubations for 2 weeks.

Paraffin section were prepared (6 um thick) stained with H\&E and Masson trichrome. Frozen sections (6um) were prepared to study the activity of both alkaline phosphatase and Succinic dehydrogenase enzymes.

Quantitative study was done by using image analyzer for estimating the glomerular area, area percentage of collagen fibers distributions and optical density of both alkaline phosphatase enzyme activity in glomerulus and succinic dehydrogenase enzymes activity in renal tubules.

\section{Results \\ I-Morphological changes (fig1,11) \\ (A)- Hamatoxylin and Eosin stain sections}


The kidney divided into an outer cortex and inner medulla. The cortex contains numerous renal corpuscles, proximal and distal convoluted tubules. The proximal convoluted tubules are lined with tall cubical darkly acidophilic cells. The distal convoluted tubule is lighter in staining and wider lumen. The medulla contain loops of Henle and collecting tubules. Loop of Henle is lined by simple squamous epithelium in thin segment and low cuboidal epithelium in thick segment. Collecting tubules and ducts are pale in staining and lined by a simple cuboidal epithelium.

The second group which treated with Sodium nitrate, and The fourth group which treated with sodium nitrate and sun set show congested glomeruli and blood capillaries. Both proximal and distal convoluted tubules are dilated with some degenerated cells and significant increase in glomerular area. Changes in the seventh group it was noticed recovery changes. No significant changes in glomerular area, while in the other groups the observed changes are more or less similar to the normal renal tissues.

\section{(B)- Masson Trichrome Stain sections}

In the control group normal fibrous tissue distributions between renal tissues are observed.

The second group and the fourth groups shows marked increase in fibrous connective tissue distribution mainly in glomerulus and in between renal tubules
The seventh group shows no distinct changes in the distribution of the connective tissue in the renal tissue.

\section{1-Histochemical results}

Changes in the Alkaline phosphatase and succinic dehydrogenase enzymes activities were estimated in optical density (O.D) unit and was measured by using the image analyzing computer system. The area examined was mainly the glomerulus in Alkaline phosphatase and the renal tubules in succinic dehydrogenase.

\section{(A) Changes in Alkaline phosphatase} enzyme activity.

The first group (Control group) shows normal distribution of alkaline phosphatase enzyme activity in both glomerulus and renal tubules The second group Which represents sodium nitrate treated group and fourth group shows decrease in the alkaline phosphatase enzyme activity in glomerulus while in the seventh group no changes were observed.

\section{(B)-Changes in succinic dehydrogenase enzyme activity:}

The first group (control group) shows intense succinic dehydrogenase enzyme activity in renal tubules.The second group, The fourth group and seventh group shows decrease in the succinic dehydrogenase enzyme activity when compared the control group.. 
Table (1) Changes in Renal Glomerular Area Under the Effect of Sodium Nitrate and Sun Set Yellow.

\begin{tabular}{|c|c|c|c|c|c|c|c|}
\hline Area $\left(u^{2}\right)$ & Group1 & Group2 & Group 3 & Group 4 & Group5 & Group 6 & Group 7 \\
\hline Mean & 3956.474 & 8183.720 & 5442.089 & 7202.862 & 4581.335 & 6248.504 & 4006.670 \\
\hline Min & 2318.126 & 4996.294 & 3874.700 & 3288.197 & 4623.240 & 3175.357 & 3080.411 \\
\hline Max. & 6269.833 & 15575.387 & 7717.752 & 10857.721 & 5869.239 & 11328.313 & 4645.688 \\
\hline SD & 1502.488 & 3280.079 & 1133.233 & 2452.132 & 1327.194 & 2600.264 & 606.450 \\
\hline SEM & 531.210 & 1159.683 & 400.658 & 680.099 & 593.539 & 694.950 & 247.582 \\
\hline \multirow[t]{2}{*}{ T-Test } & & $\begin{array}{c}\text { Control VS } \\
\text { Group2 } \\
\end{array}$ & Control VS Group3 & $\begin{array}{c}\text { Control VS } \\
\text { Group4 } \\
\end{array}$ & Control VS Group5 & $\begin{array}{c}\text { Control VS } \\
\text { Group6 }\end{array}$ & $\begin{array}{c}\text { Control VS } \\
\text { Group7 }\end{array}$ \\
\hline & & 0.0051 & 0.0424 & 0.0033 & 0.4629 & 0.0343 & 0.9402 \\
\hline $\mathrm{P}$ value & & $p>0.01$ & $\mathrm{p}>0.05$ & $\mathrm{p}>0.01$ & $\mathrm{p}>0.05$ & $\mathrm{P}<0.05$ & $\mathrm{p}>0.05$ \\
\hline Significance & & Sig. Inc. & Sig. Inc. & Sig. Inc. & NS & Sig. Inc. & NS \\
\hline
\end{tabular}

Figure (1) Changes in Renal Glomerular Area Under The Effect of Sodium Nitrate and Sun Set Yellow.

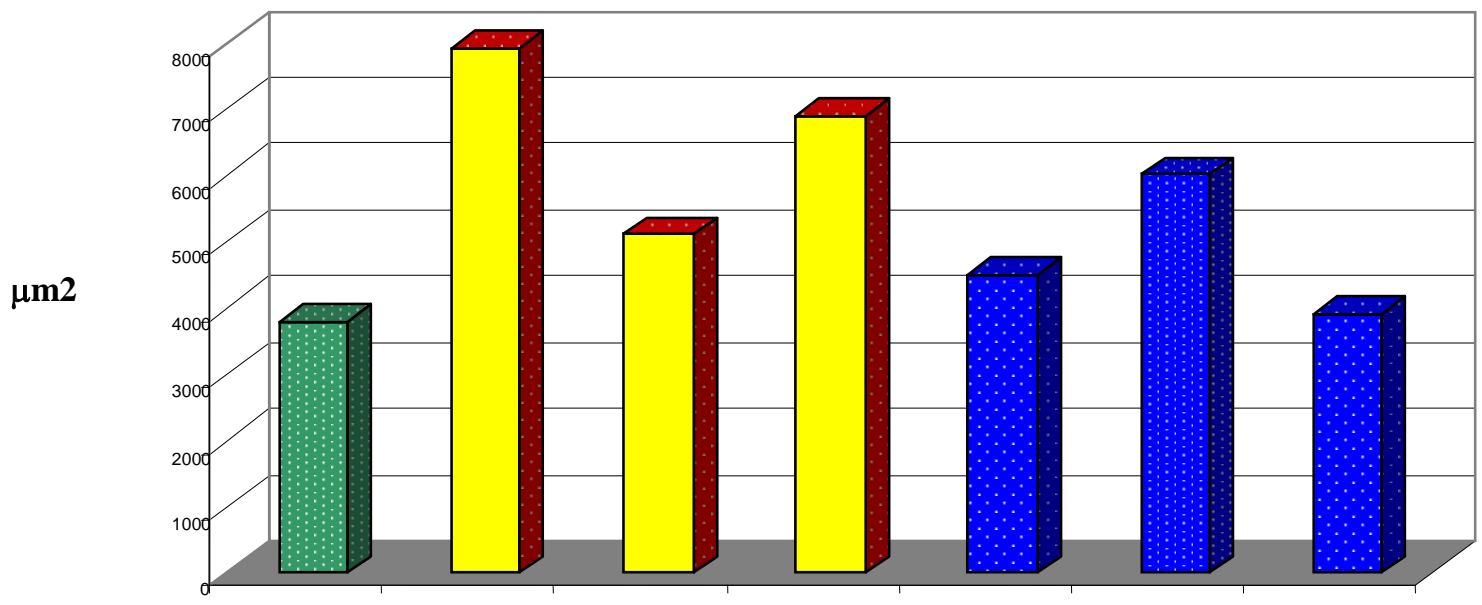

Group I Group II Group III Group IV Group V Group VI Group VII 
Table (2) Changes in Renal Fibrous Tissue Under the Effect of Sodium Nitrate and Sun Set Yellow.

\begin{tabular}{|c|c|c|c|c|c|c|c|}
\hline Area $\left(u^{2}\right)$ & Group1 & Group2 & Group 3 & Group 4 & Group5 & Group 6 & Group 7 \\
\hline Mean & 0.154 & 0.263 & 0.154 & 0.166 & 0.094 & 0.237 & 0.172 \\
\hline Min & 0.107 & 0.170 & 0.071 & 0.085 & 0.080 & 0.096 & 0.083 \\
\hline Max. & 0.225 & 0.332 & 0.223 & 0.225 & 0.126 & 0.349 & 0.298 \\
\hline SD & 0.040 & 0.063 & 0.054 & 0.046 & 0.022 & 0.108 & 0.075 \\
\hline SEM & 0.014 & 0.021 & 0.019 & 0.017 & 0.011 & 0.044 & 0.030 \\
\hline \multirow[t]{2}{*}{ T-Test } & & $\begin{array}{c}\text { Control VS } \\
\text { Group2 } \\
\end{array}$ & $\begin{array}{c}\text { Control VS } \\
\text { Group3 } \\
\end{array}$ & $\begin{array}{c}\text { Control VS } \\
\text { Group4 } \\
\end{array}$ & $\begin{array}{c}\text { Control VS } \\
\text { Group5 } \\
\end{array}$ & $\begin{array}{c}\text { Control VS } \\
\text { Group6 } \\
\end{array}$ & $\begin{array}{c}\text { Control VS } \\
\text { Group7 } \\
\end{array}$ \\
\hline & & 0.0008 & 0.9913 & 0.5993 & 0.0210 & 0.0670 & 0.5752 \\
\hline$P$ value & & $\mathrm{P}<0.01$ & $\mathrm{P}>0.01$ & $p>0.05$ & $\mathrm{P}<0.05$ & $\mathrm{P}>0.05$ & $\mathrm{p}>0.05$ \\
\hline Significance & & Sig. Inc & NS & NS & Sig. Dec & NS & NS \\
\hline
\end{tabular}

Figure (2) Changes in Renal Fibrous Tissue Under The Effect of Sodium Nitrate and Sun Set Yellow.

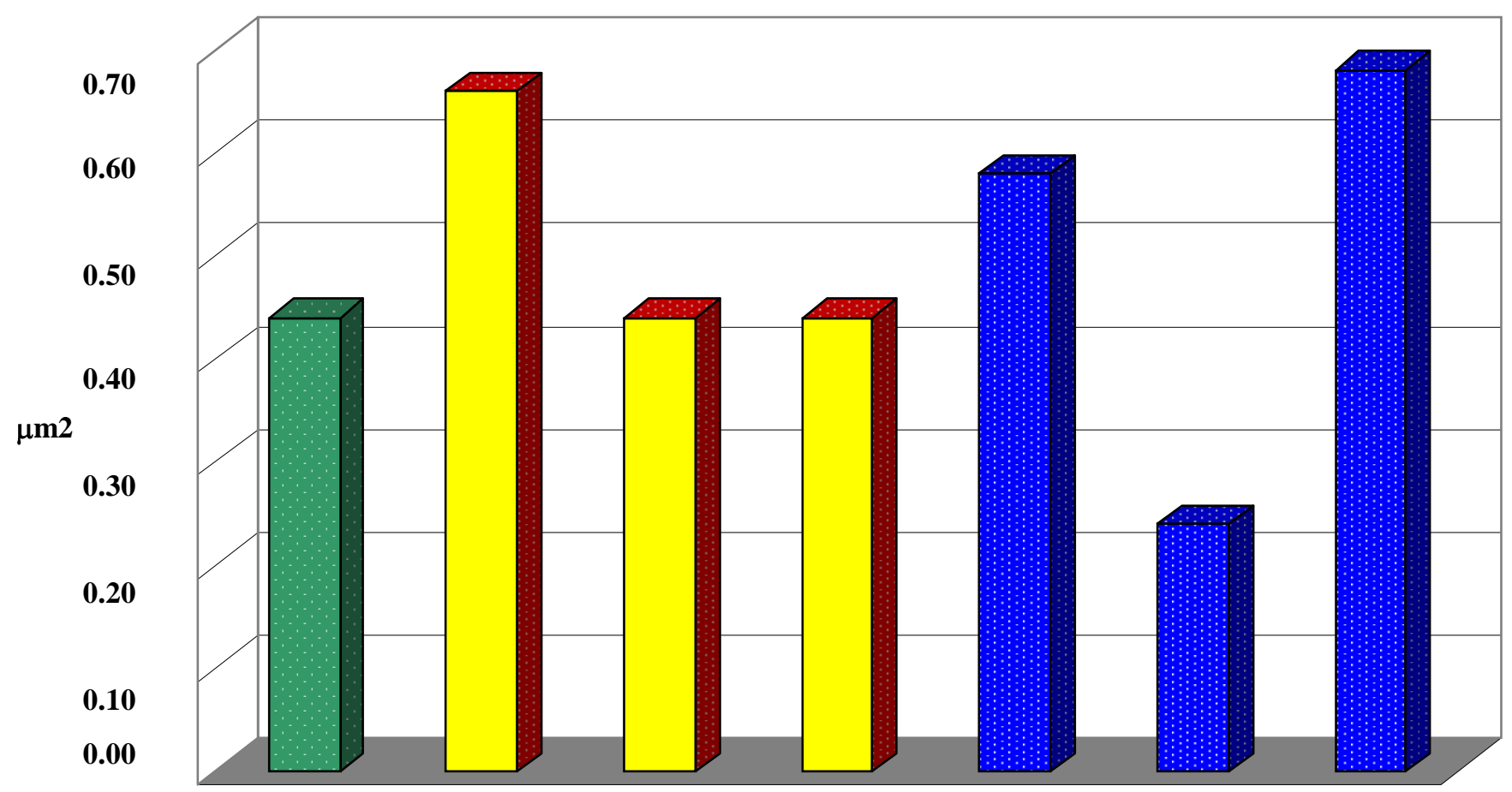


Table (3) Changes in Renal Glomerular Alkaline Phosphatase Enzyme Activity Under the Effect of Sodium Nitrate and Sun Set Yellow.

\begin{tabular}{|c|c|c|c|c|c|c|c|}
\hline O.D. & Group1 & Group2 & Group 3 & Group 4 & Group5 & Group 6 & Group 7 \\
\hline Mean & 1.365 & 0.894 & 0.775 & 0.271 & 1.051 & 0.936 & 1.381 \\
\hline Min & 1.590 & 1.138 & 0.937 & 0.570 & 0.752 & 1.026 & 1.381 \\
\hline Max. & 2.007 & 1.503 & 1.111 & 1.305 & 2.171 & 1.521 & 2.170 \\
\hline SD & 0.153 & 0.138 & 0.063 & 0.306 & 0.593 & 0.189 & 0.328 \\
\hline SEM & 0.062 & 0.056 & 0.026 & 0.125 & 0.242 & 0.007 & 0.134 \\
\hline \multirow[t]{2}{*}{ T-Test } & & $\begin{array}{c}\text { Control VS } \\
\text { Group2 } \\
\end{array}$ & $\begin{array}{c}\text { Control VS } \\
\text { Group3 } \\
\end{array}$ & $\begin{array}{c}\text { Control VS } \\
\text { Group4 }\end{array}$ & $\begin{array}{c}\text { Control VS } \\
\text { Group5 } \\
\end{array}$ & $\begin{array}{c}\text { Control VS } \\
\text { Group6 }\end{array}$ & $\begin{array}{c}\text { Control VS } \\
\text { Group7 }\end{array}$ \\
\hline & & 0.0002 & 0.0003 & 0.0001 & 0.1257 & 0.0002 & 0.8846 \\
\hline $\mathrm{P}$ value & & $p>0.001$ & $\mathrm{p}>0.001$ & $\mathrm{p}>0.001$ & $\mathrm{p}>0.05$ & $\mathrm{P}<0.001$ & $\mathrm{p}>0.05$ \\
\hline Significance & & Sig. Dec. & Sig. Dec. & Sig. Dec. & NS & Sig. Dec. & NS \\
\hline
\end{tabular}

fig. (3) Changes in Renal Glomerular Alkaline Phosphatase Enzyme Activity Under The Effect of Sodium Nitrate and Sun Set Yellow.

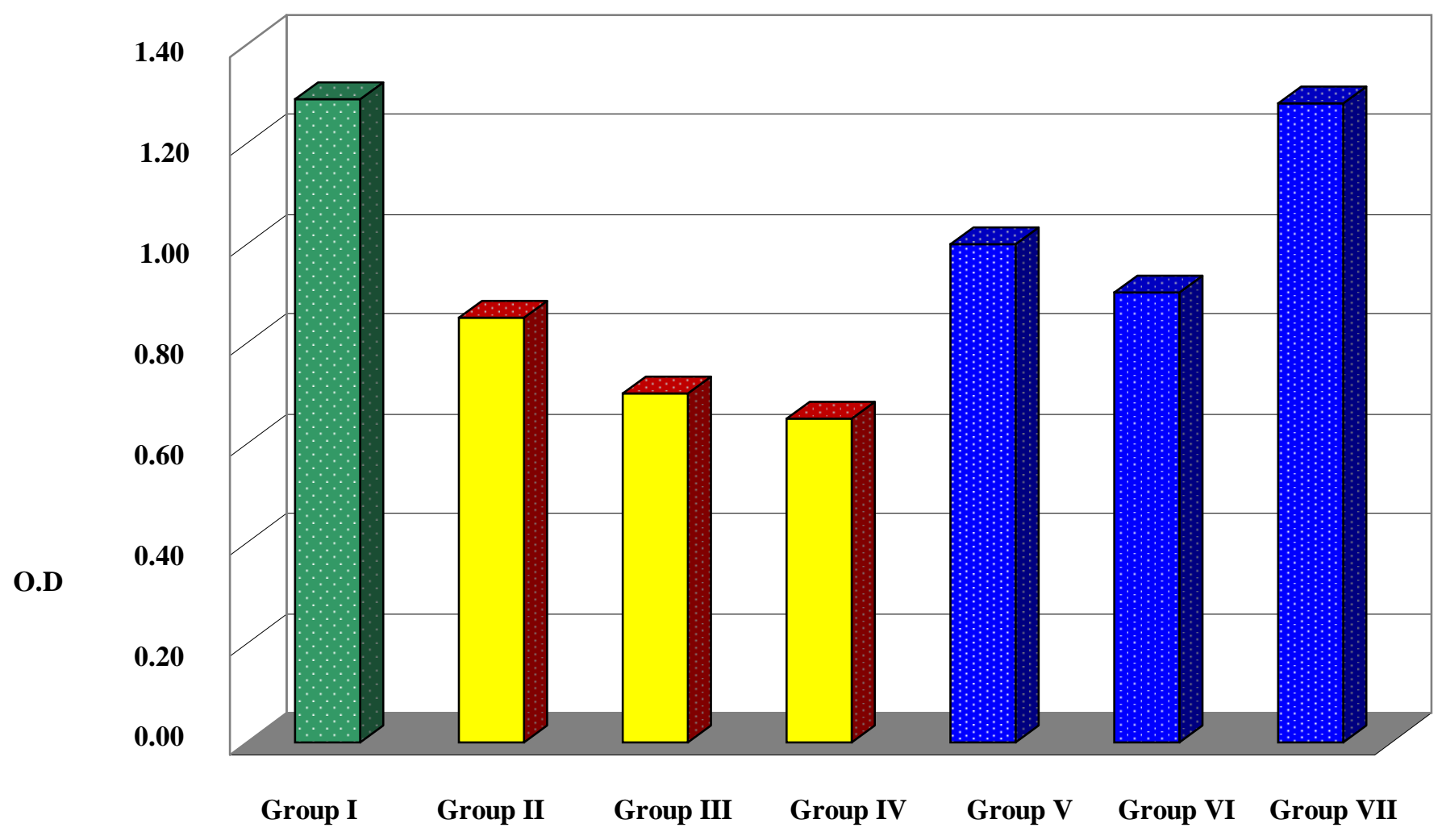


Table (4) Changes in Succinic Dehydrogenase Enzyme Activity in renal tubules Under the Effect of Sodium nitrate and sun set yellow.

\begin{tabular}{|c|c|c|c|c|c|c|c|}
\hline O.D. & Group1 & Group2 & Group 3 & Group 4 & Group5 & Group 6 & Group 7 \\
\hline Mean & 0.303 & 0.282 & 0.221 & 0.271 & 0.299 & 0.204 & 0.226 \\
\hline Min & 0.252 & 0.280 & 0.199 & 0.209 & 0.241 & 0.180 & 0.187 \\
\hline Max. & 0.556 & 0.574 & 0.403 & 0.538 & 0.665 & 0.380 & 0.420 \\
\hline SD & 0.129 & 0.130 & 0.090 & 0.125 & 0.155 & 0.085 & 0.097 \\
\hline SEM & 0.053 & 0.053 & 0.037 & 0.051 & 0.063 & 0.035 & 0.040 \\
\hline \multirow[t]{2}{*}{ T-Test } & & $\begin{array}{c}\text { Control VS } \\
\text { Group2 } \\
\end{array}$ & $\begin{array}{c}\text { Control VS } \\
\text { Group3 } \\
\end{array}$ & $\begin{array}{c}\text { Control VS } \\
\text { Group4 } \\
\end{array}$ & $\begin{array}{c}\text { Control VS } \\
\text { Group5 } \\
\end{array}$ & $\begin{array}{c}\text { Control VS } \\
\text { Group6 } \\
\end{array}$ & $\begin{array}{c}\text { Control VS } \\
\text { Group7 } \\
\end{array}$ \\
\hline & & 0.8105 & 0.1202 & 0.5753 & 0.9498 & 0.0640 & 0.1514 \\
\hline$P$ value & & $\mathrm{p}>0.05$ & $p>0.05$ & $p>0.05$ & $p>0.05$ & $p>0.05$ & $p>0.05$ \\
\hline Significance & & NS & NS & NS & $\mathrm{NS}$ & $\mathrm{NS}$ & $\mathrm{NS}$ \\
\hline
\end{tabular}

figure (4) : Changes in Renal Tubuler Succinic Dehydrogenase Enzyme Activity Under The Effect of Sodium Nitrite and Sun Set Yellow.

O.D. $\quad 0.15$

0.30

0.25

$\mathbf{0 . 2 0}$

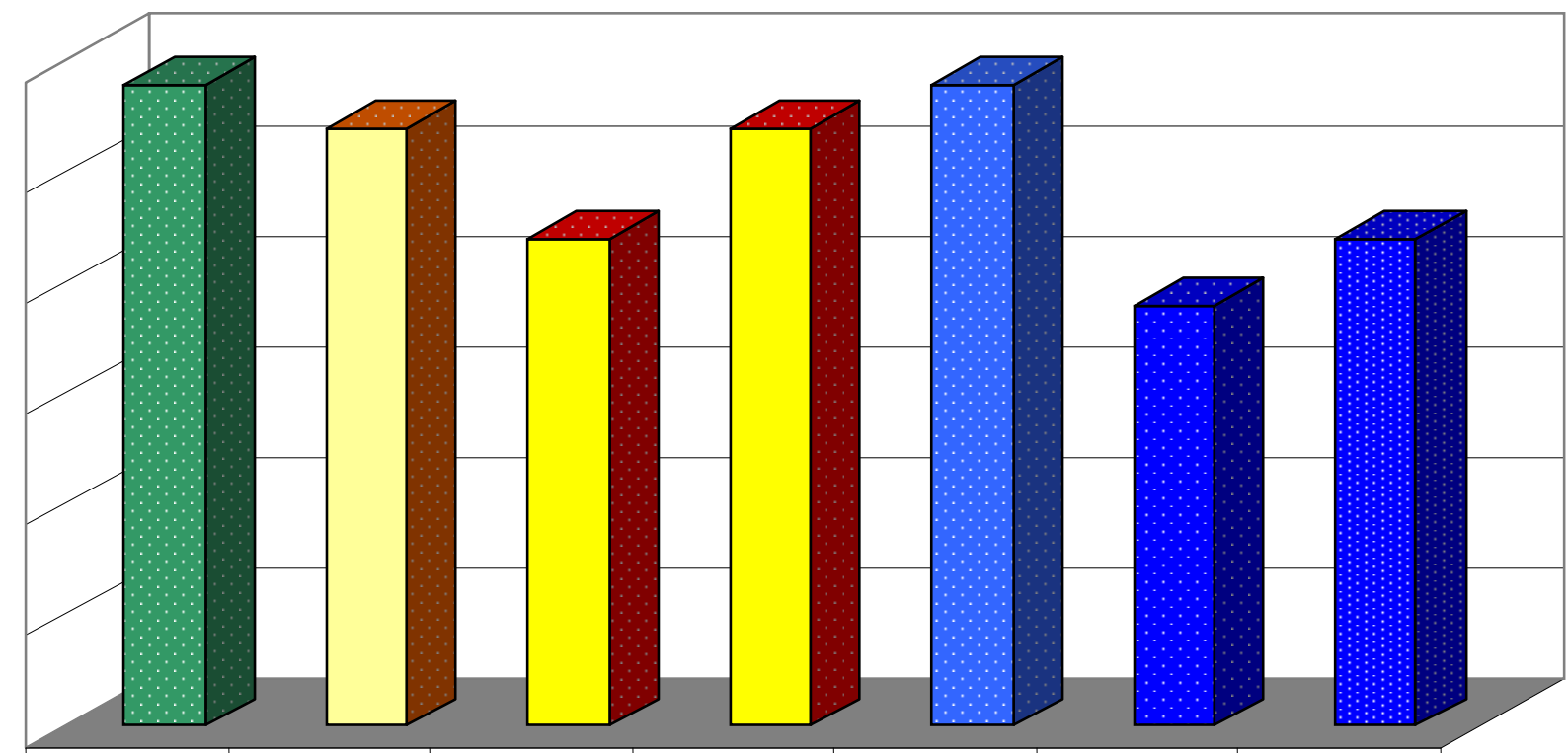

0.00

Group I Group II Group III Group IV Group V Group VI Group VII 


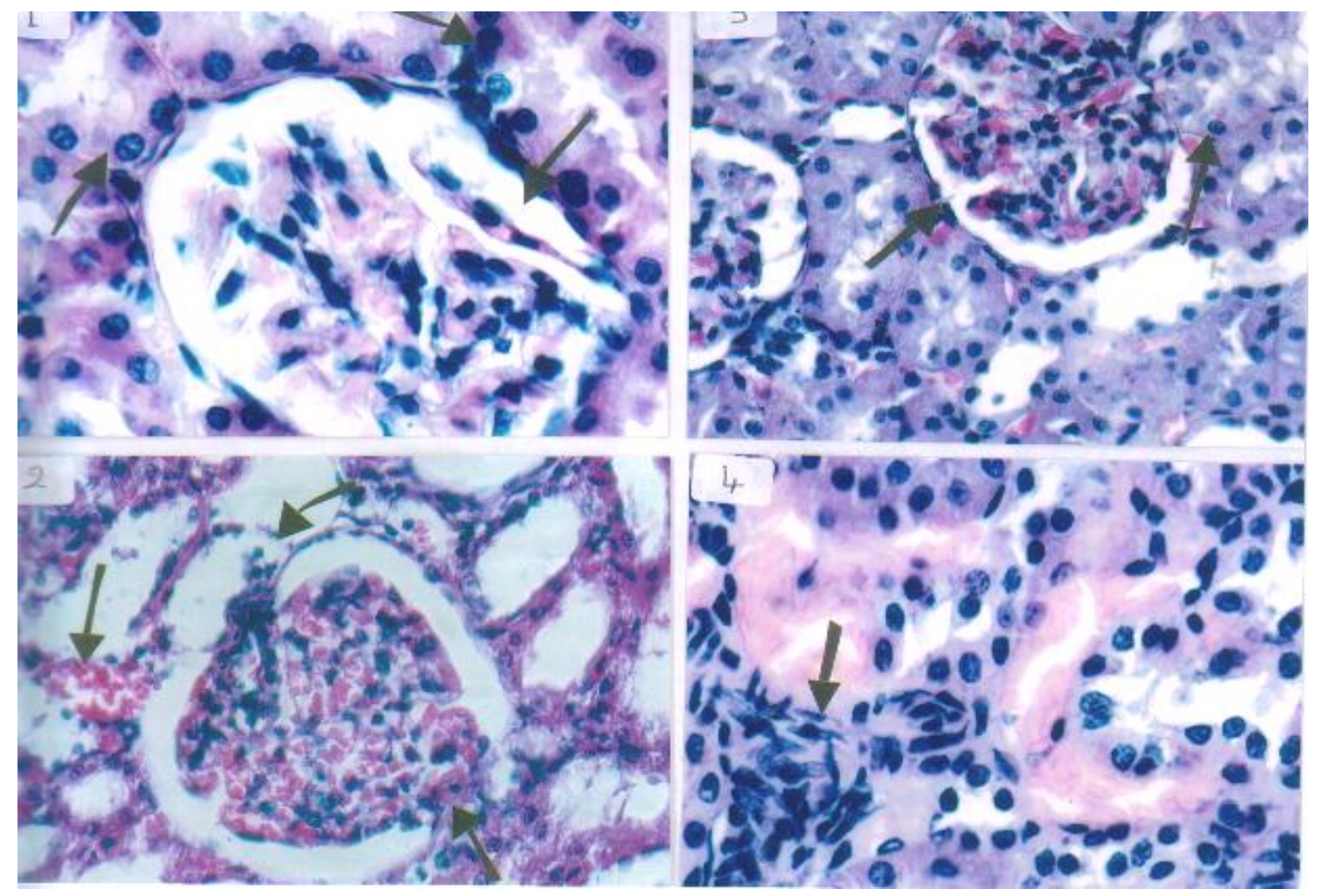

Fig 1: Collective photomicrograph of sections in the rat kidney

1- Group 1"control group " shows the normal glomeruli, proximal and distal convoluted tubules.

2- Group 2"treated with sodium nitrate" shows congested blood capillaries and dilated proximal and distal convoluted tubules and degenerated cells.

3- Group 4"treated with sodium nitrate and sun set" shows congested glomerulus $\&$ dilated proximal and distal convoluted tubules vaculations and degeneration of some cells.

4-Group 7"sodium nitrate and sun set recovery" shows some degenerated cells surrounded by fibroblasts. (Hx\&E X500). 

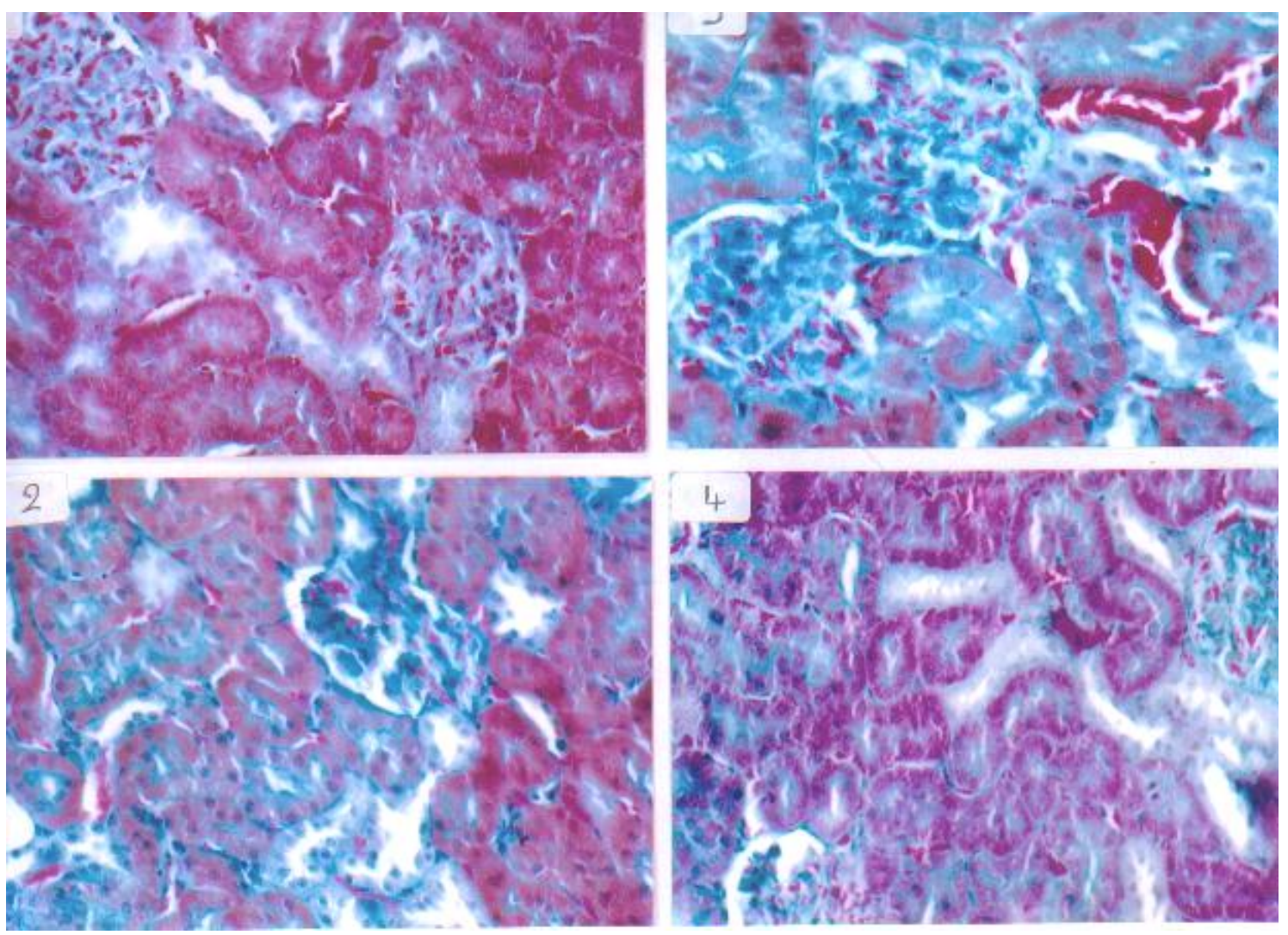

Fig 2: Collective photomicrograph of sections in the rat kidney

1- Group 1"control group" shows normal C.T. distributions.

2- Group 2 "treated with sodium nitrate" shows marked increase in fibrous C.T. in glomerulus and in-between renal tubulues.

3- Group 4"treated with sodium nitrate and sun set" shows C.T. distributions similar to control group.

4-Group 7"sodium nitrate and sun set" shows C.T. distributions similar to control group. (Masson trichrome stain x 500). 


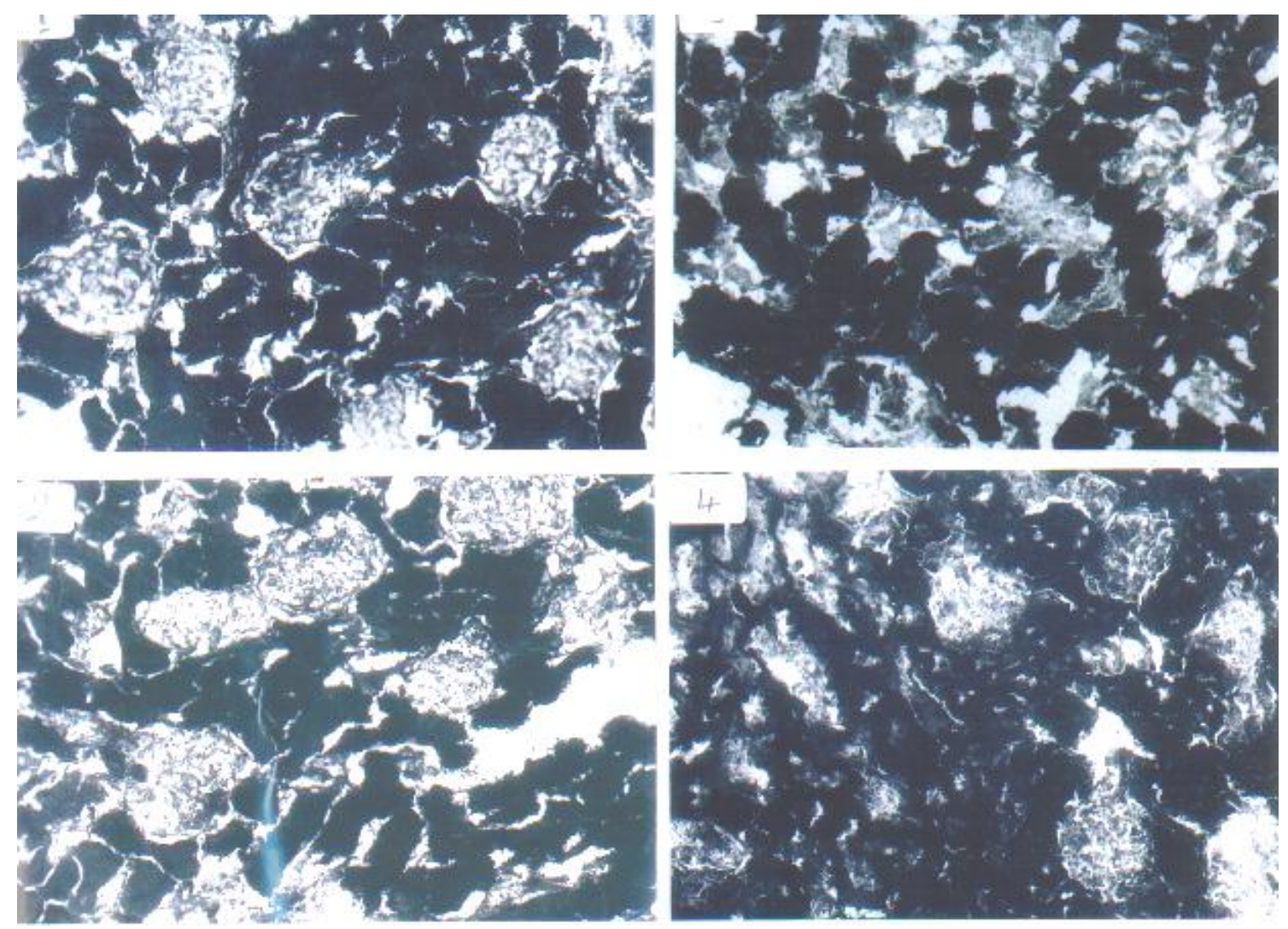

Fig 3: Collective photomicrograph of a sections in the rat kidney

1-Group 1 "control group" shows alkaline phosphatase enzyme activity distribution in the tubules and glomerulus.

2-Group 2"treated with sodium nitrate" shows decrease alkaline phosphatase enzyme activity in glomeruli.

3-Group4"treated with sodium nitrate and sun set" shows decrease alkaline phosphatase enzyme activity.

4-Group 7)"sodium nitrate and sun set recovery" shows alkaline phosphatase enzyme activity similar to control group. (Gomori stain x 500) 

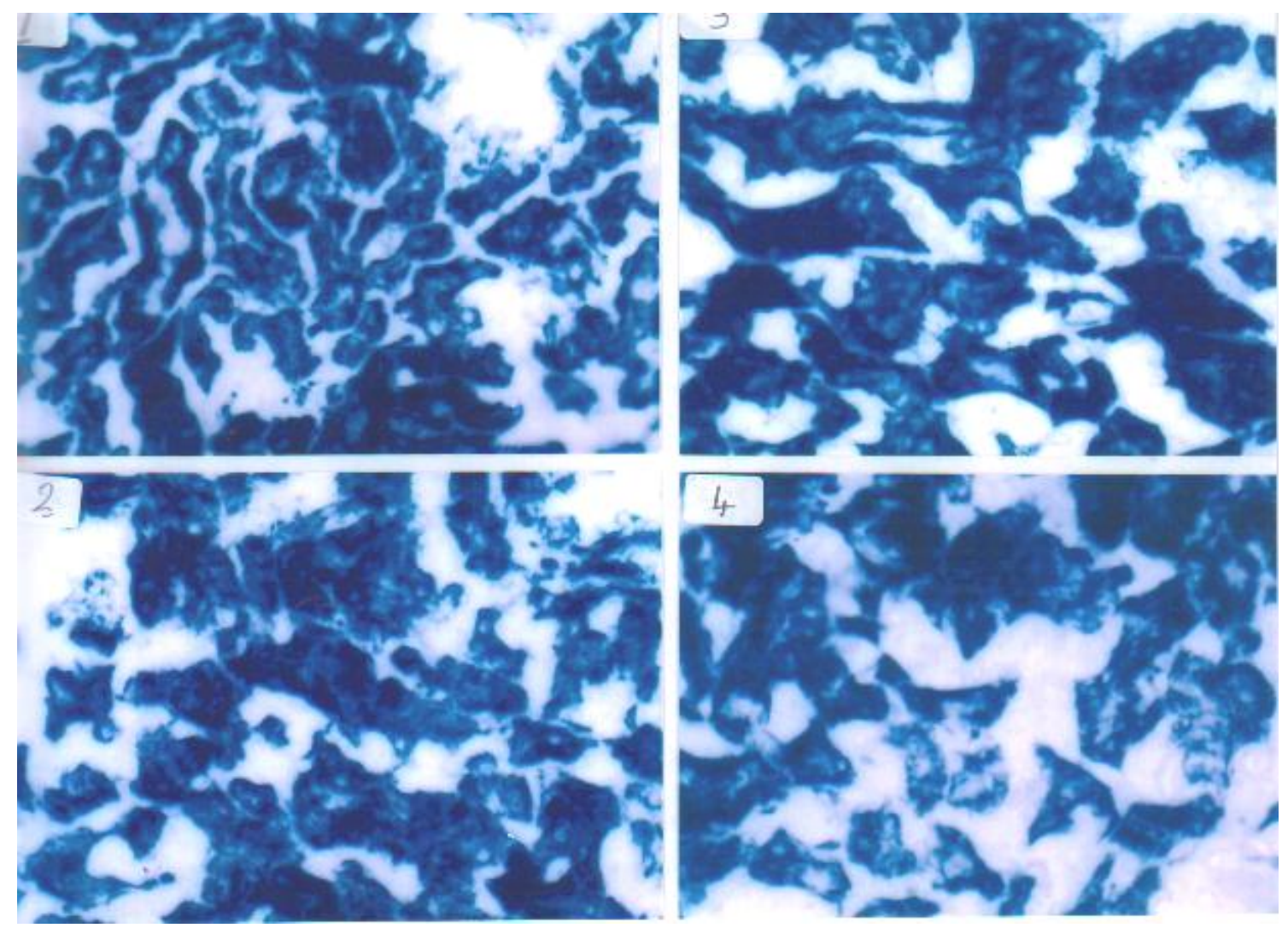

Fig 4: Collective photomicrograph of sections in the rat kidney

1-Group1 "control group" shows intense succinic dehydrogenase enzyme activity in renal tubules.

2-Group 2"treated with sodium nitrate" shows decrease succinic dehydrogenase enzyme activity.

3-Group 4"treated with sodium nitrate and sun set" shows decrease in succinic dehydrogenase enzyme activity in renal tubules.

4-Group7"treated with sodium nitrate and sun set" shows no changes in succinic dehydrogenase enzyme activity in renal tubules.

(Nachlas technique X500). 


\section{Discussion}

It has been noticed that people especially children at the age of nursery usually used food containing colorant and additives with great amounts which attracts their attention.

Appetite is a concept largely influenced by vision, when we look at a certain food; we first appreciate its image. If we don't like its color, we don't feel like purchasing it. Before we buy a food, first the food has to capture our attention, seize our appetite. Colors play a large role in attracting us to foods. So, food industries, realizing this basic human tendency, play with the color concept cunningly, for the sake of having us consume their products in greater quantities with more appetite. Food additives are substances that not normally consumed as a food by itself and not normally used as a typical ingredient of the food, whether or not it has nutritive value.

Nowadays, food additives are considered to be one of the difficult problems in the food industry. All food additives, whether actually in use or being proposed for use, should be subjected to appropriate toxicological testing and evaluation? The natural additives are safer and appreciated the addition of food preservatives and coloring.

Synthetic compounds should be either omitted completely or highly restricted to lower levels due to its side effects.

The present study was carried out on adult albino rats to evaluate the side effects of these food additives on its kidney.

It is known that nitrate and nitrite and dimethyl amine may react in the gastrointestinal tract synthesizing, the harmful dimethynitrosoamine substances which had adverse effects on animal and human organs (Swan, 1975), nitrate and nitrite also cause pathological changes in rat liver (Gracia et al., 1987) and kidney (Gojer \& Sawant, 1992 and Anthony et al., 1994), pleasant chicks liver and kidney (Storand and Persin, 1983).

Also nitrite reacts with amines to produce nitrosamines and with amides to produce nitrosamides. Nitosamines and nitrosomides constitute the $\mathrm{N}$-nitroso compounds (NNC) and the reaction with nitrite is called nitrosation, nitrosamines readily induced tumours of the liver, oesophagus, kidney, nasal cavity and pancreas and notrosamine chiefly induce tumours of glandular stomach, small intestine and nervous as well as lymphoid systems the tissue affections dependences on the species (NNC) and the treatment system (Sidney, 1986).

Nitrates and nitrites are environmental pollutants present in food \& water and it is suggested that they may be contribute to the etiology of kidney diseases and problems related to immunity in domestic fowls.

Kidney has a vital physiological role in case of toxicity, in this study we try to evaluate the effects of nitrites \& sunset yellow on the renal morphology.

Studies of the histochemical activities of succinic dehydrogenase \& alkaline phosphatase enzymes facilitate understanding the effect of food additives on renal tissue.

We selected two agents of food additives substances to study their effects on the kidney of albino rat, the first one was the sodium nitrate as a food preservative and the second was the sunset yellow as a one of food colorants singly or in combination.

We give sodium nitrate $\&$ sunset yellow by a gastric tube for one month then stop the intubations for another 2 weeks to show the possibility of recovery.

In the present study, it was found that sodium nitrate causes dilatation and congestion of glomerular and peritubular capillaries. The lumen of renal tubules (proximal and distal convoluted tubules) becomes dilated with degenerations of its cells. This action occur when sodium nitrate given alone or in combination with sunset yellow.

Also, sodium nitrate induces fibrosis around glomerulus and renal tubules, which may be due to nitric oxide (NO) formations, which causes vascular smooth muscle relaxation. This leads to dilatations of their lumens and increases their blood flow.

The permanent vasodilatation and congestion causes cellular hypoxia and 
death, which may be followed by fibrosis (Took J.E., 1996).

In sunset yellow given groups there is many areas of cellular infiltrations which may be due to allergies (Wood, 1980) and hypersensitivity to sunset antigens that leads to formations of antigen - antibody complex which deposited in glomerular subendothelial, mesangium and tubular cells ,once immune complex are deposited, injury induced by both cellular and soluble mediators including neutrophils which releases proteases and monocytes macro-phage lymphocyte and natural killer which release cytokines, cytotoxic cell mediators growth factors also mesangium cells produces inflammatory response by releasing cytokines this leads to glomerulo-nephritis and interstitial nephritis.

Chronic glomerulonephritis leads to glomerular fibrosis and chronic interstitial nephritis leads to peritubular fibrosis (Stanley et al., 1999).

Our findings are agreement with (Rowe et al., 1994) which decided that sunset has the following side effects articaria (hives), Rhinitis (runny nose) nasal congestion. Eosinophilactic response, purpura (bruising).

In the present study the alkaline phosphatase enzyme activity was significantly decreased as $(\mathrm{p}<0.05)$ in both groups given sodium nitrate and sunset yellow singly or in combination in comparison to control group, our findings are in agreement with (Moriyama \& Nelson, 1987 and Kurimoto et al., 1984), Which postulated that nitrate in a partly diffusible anion that can cross the plasma membrane and significantly affect membrane enzymes e.g. (adenosine triphos-phate) activity (Moriyama and Nelson, 1987) inhibit the energy metabolism of the cells and damage cell membrane integrity (Kurimoto et al., 1984).

Our findings are also in agreement with (Staewsond et al., 1973 and Atef et al., 1991) hence food preservative as sodium nitrate and food coloring agents as sunset has many adverse effects and harmful to human health so we must avoid food stuffs containing these substances as much as possible.

\section{References}

1. Anthony M.L.; Gartland K.P.; Beddell C.Rand Nicholson J.K.,(1994): Studies of the biochemical toxicology of uranyl nitrate in the rat. Arch. Toxicol 68 (1):43-53.

2. Atef M.; Abo-Norage M.A.M.; Hanafy M.S.M. and Agag A.E., (1991): Pharmacotoxicological aspects of nitrate and nitrite in domestic fowls. Brit. Poult Sci. 32: 399-404.

3. Babu S. and Shenolikar I.S. (1995): Health and nutritional implications of food colors. Indian J. Med. Res. 102: 245-249.

4. El-Saadany, S.S., (1991): Biochemical effect of chocolate coloring and flavoring like substances on thyroid function and protein biosynthesis. Die. Nahrung. 35 (4): 335343.

5. Furia T.E., (1972): Handbook of Food Additives. $2^{\text {nd }}$ ed. CRC Press, New York. P. 587-615.

6. Garcia Roche M.O.; Castillo A., Gonzalez T.; Grillo M., and Rodriguez N. (1987): Effect of ascorbic acid on the hepatotoxicity due to the daily intake of nitrate, nitrite and dimethylamine. Nahrung. 31 (2): 99-104.

7. Gojer M. and Sawant V. (1992): Uranyl nitrate induced corpuscular derangement: an early indication of induced acute renal failure. 1nd. J. Exp. Biol. 30 (2): 119-121.

8. Kurimotom. Tsubone H. and Tsujii, (1984): Effects of nitrate and nitrites chemical intermediate of inhaled nitrogen dioxide on membrane components of Red Blood Cells of rats, toxicol apple pharmacol. 74: 10-16.

9. Marmion D.M., (1984): Handbook of U.S. colorants for foods, drugs and cosmetic. $2^{\text {nd }}$ ed. John Wiley \& Sons. New York. Chichester. Brisbane, Toronto. Singapore. P. 3-23.

10. Moriyama Y. and Neslon N.C., (1987): The purified Atpase from chromaffin granule membranes is an anion-dependent proton pump. Biol Chem. 262: 9175-9180.

11. Rowe K.S. and Rowe K.J., (1994): Synthetic food coloring and behavior: a dose response effect in a double-blind, placebo-controlled, repeated - easures study.J. Pediatr. 125 (5 pt 1), 691 - 698.

12. Salah S.H., (1994): Biochemical studies on some synthetic food colorants. A thesis submitted in partial fulfillment of the requirement for the Degree of ph.D in Agriculture. Biochemistry. Department of 
Biochemistry. Faculty of Agriculture. Cairo university.

13. Shaker A.M.H.; Ismail I.A. and EilNemr S.E., (1989): Effect of different food stuff colorants added to casein diet on biological evaluation. Bull. Nutr. Inst. Cairo, Egypt. 9 (1), 77 - 86.

14. Sidney S.M., (1986): Effects of vitamins C and $\mathrm{E}$ on $\mathrm{N}$-nitroso compound formation, carcinogenesis and cancer. Cancer 58: 1842-1850.

15. Stanley L. Robbins; Ramzi S. Cotran; Vindry Kumar and Tucker Collins, (1999) : Robbins Pathologic Basis of Disease. Sixth edition, W.B. Saunders Company; 407-501.

16. Stoewsand G.S.;Anderson J.L.and Lee C.Y., (1973): Nitrate induced methaemoglobinaemia in guinea pigs: influence of diets containing beets with varying amounts of nitrate, and the effect of ascorbic acid and methionine. J. Nutr. 103: 419-424.
17. Stornad Z. and Persin M., (1983): Experimental poisoning of pheasant chicks with nitrates and nitrites in their drinking water. Vet. Med. 28: 541-547.

18. Swann P.F., (1975): The toxicology of nitrate, nitrite and N-nitroso compounds. J Sci. Food Agrc. 26: 1761-1770.

19. Taylor R.J., (1980): Food Additives. John Wiley \& Sons. Chichester. New York. Brisbane. Toronto. P. 12-119.

20. Tooke J.E., (1996) : Endothelium : The main actor or choreographer in the remodeling of the microvasculature in diabetes ? Diabetographia; 745-746.

21. Walker R., (1975): Naturally occurring nitrate / nitrite in food. J. Sci. Food Agrc. 26: 1735-1742.

22. Wood P.A., (1980): The molecular pathology of chronic nitrate intoxication in domestic animals: a hypothesis. Vet. And Hum. Toxicol. 22: 26-27 


\section{دراسة مجهرية لتاثير بعض المواد المضافة للأغذية علنالكلى فى

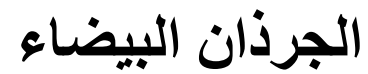

\section{عبد التواب محمد اسماعيل- أشرف محمود مصطفى- جمال عبد الرحمن

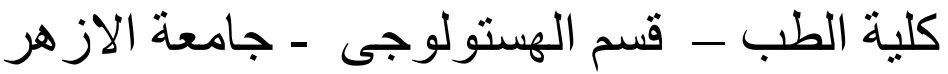

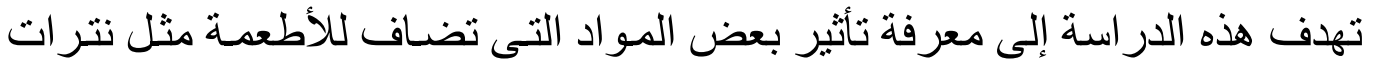

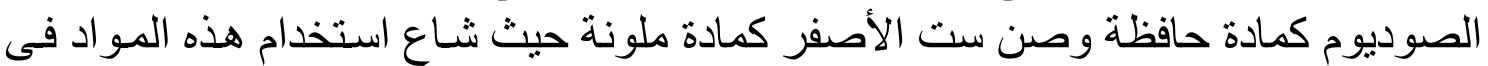

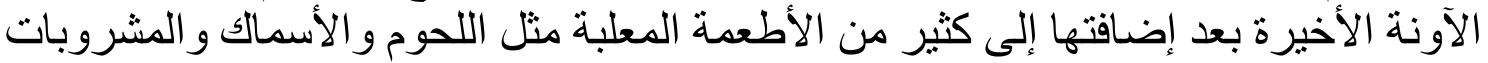

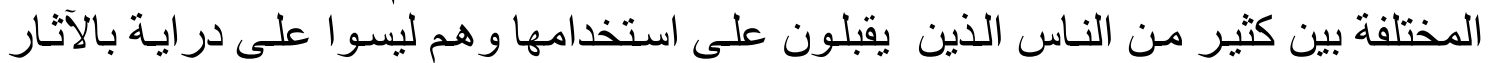

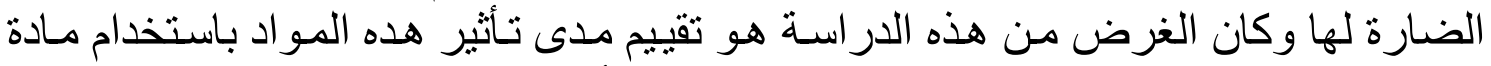

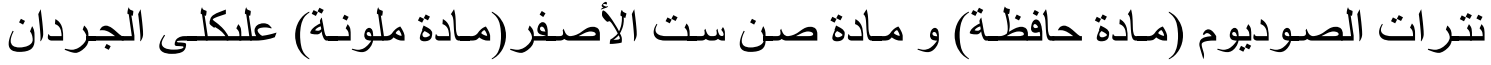

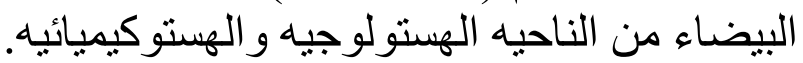
أشتمل هذا البحث على ثلاثة أجزاء البهاء: أو لا: در اسة مجهرية على نسية أجزية الكبد تحت تأثثر مادتي(نترات الصوديوم) و(صن

الأصفر ) كلاعلى حده وسويا وذللك باستعمال قطاعات شمعية مصبو غة بصبغنه

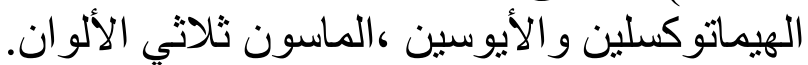

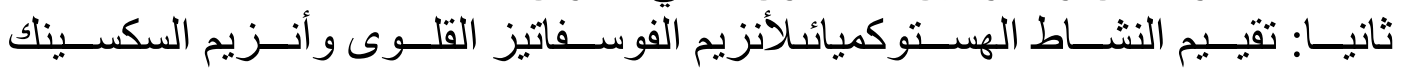

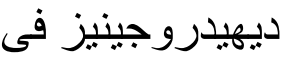
نسيج الكلى فئى

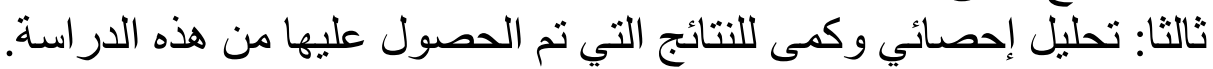

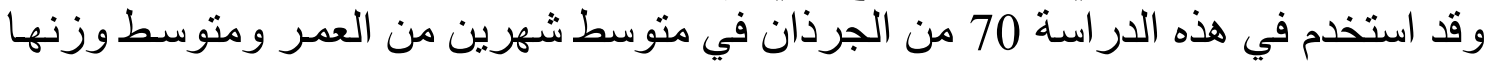

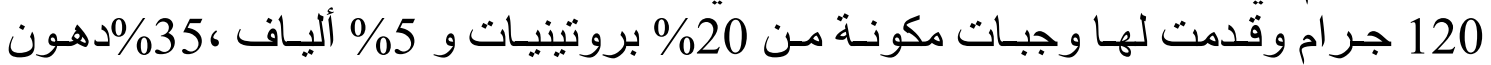

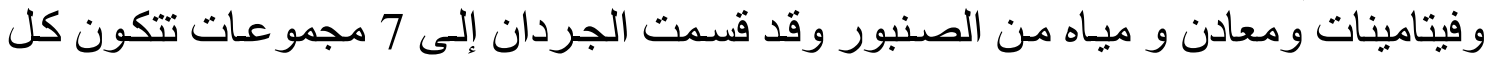

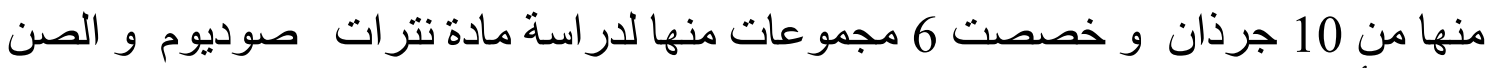

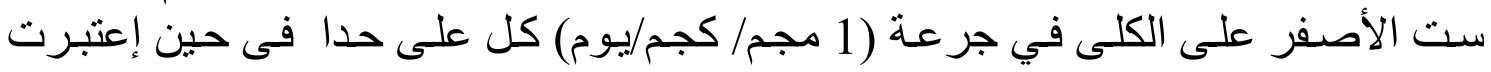

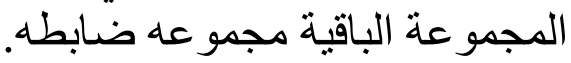

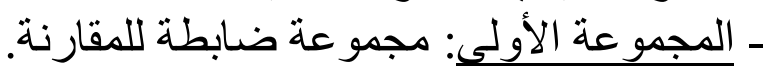

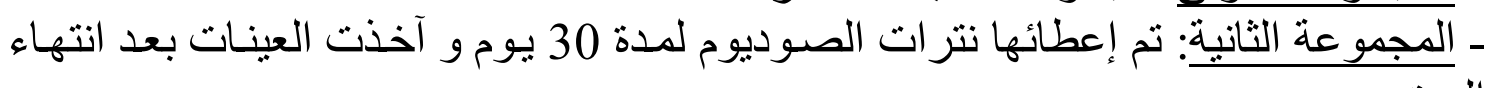

$$
\text { مباشرة. }
$$

- المجمو عة الثالثة: : تم إعطائها الصن ست الأصفر لمدة 30 يوم و آخذت العينات بعد

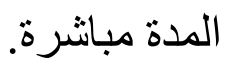

- المجمو عة الر ابعة: : تم إعطائها كل من نترات الصوديوم و الصن ست الأصفر لمدة 30 
و آخذت العينات بعد انتهاء المدة مباشرة.

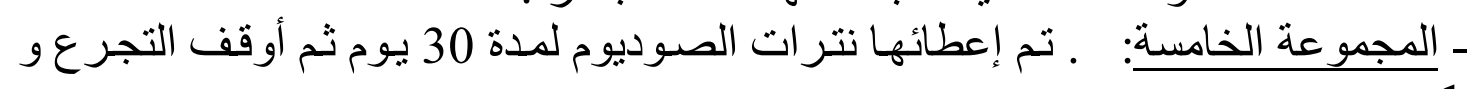

$$
\text { الفئر ان لمدة } 30 \text { يوم إعمانها }
$$

تركت

ـ المجمو عة السادسة: تم إعطائها الصن ست 30 يوم الأصفر لمدة 30 يوم ثم أوقف التجرع و تركت

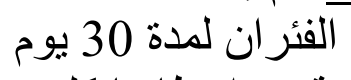

- المجمو عة السابعة: تم إعطائها كل من نترات الصوديوم و الصن ست الأصفر لمدة 30 أوقف التجرع وتركت الفئر ان لمدة 30 يوم أخرى ثم آخذت العينات.

\section{وقد دلت النتائج على ما يلإي:}

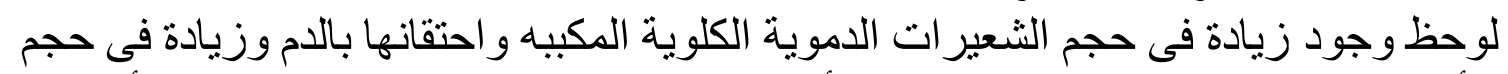

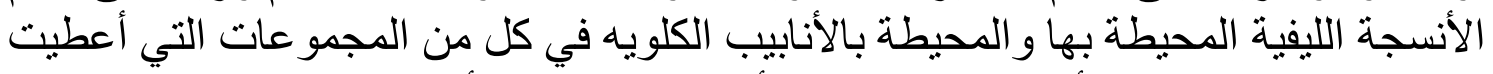

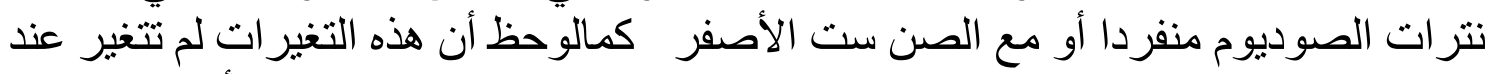

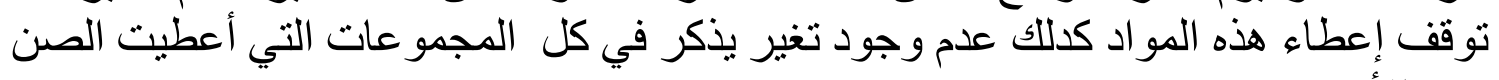

$$
\begin{aligned}
& \text { 2- التغير ات الهستو كيميائية } \\
& \text { ست الأصفر. }
\end{aligned}
$$

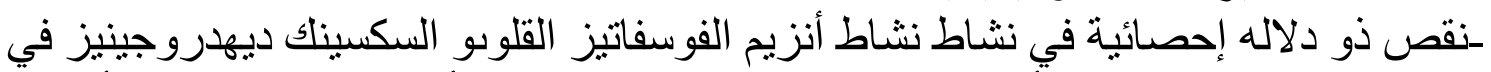

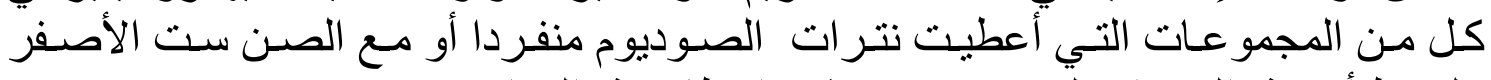

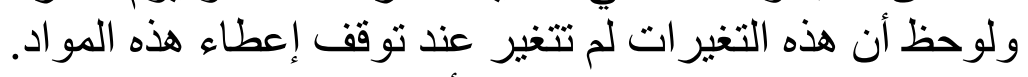

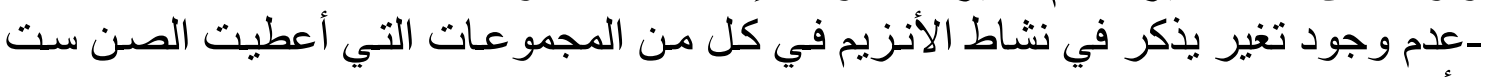
الأصفر وبعد استعر اض نتائج هذه الدر اسة في محاور ها المختلفة يمكن أن نستنتج أن هنالك تأنثير

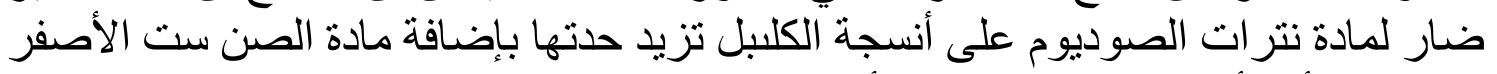

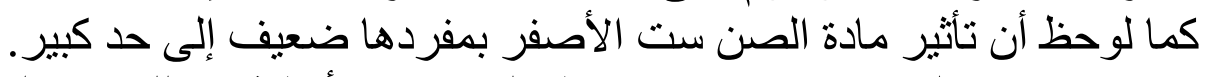
وتوصى هده الدر اسه بعدم استخدام هذه المو اد في الأغذية وكدلك عدم التعرض لها لها لفتر ات طويلة 